\title{
Stage IV Gallbladder Cancer AJCC v6
}

National Cancer Institute

\section{Source}

National Cancer Institute. Stage IV Gallbladder Cancer A/CC v6. NCI Thesaurus. Code C5740.

Stage IV includes: (Any T, Any N, M1). M1: Distant metastasis. (AJCC 6th ed.) - 2003 